\title{
PENGEMBANGAN MEDIA PRESENTASI PEMBELAJARAN BERBASIS \\ PREZI PADA MATERI DINAMIKA HIDROSFER DAN DAMPAKNYA TERHADAP KEHIDUPAN KELAS X SMA N 1 KUBUNG
}

\author{
Citra Janitaria \\ Program Studi Pendidikan Geografi \\ FIS Universitas Negeri Padang \\ Email: citrajanitaria2@gmail.com
}

\begin{abstract}
Abstrak
Penelitian ini bertujuan untuk menentukan, mendeskripsikan, dan menganalisis pengembangan media pembelajaran berbasis prezi pada materi Dinamika Hidrosfer dan Dampaknya Terhadap Kehidupan Kelas X SMA N 1 Kubung. Validasi dilakukan oleh 2 orang ahli materi, dan 2 orang ahli media. Kepraktisan dilakukan oleh 1 orang guru geografi dan 30 siswa kelas X IPS 1. Instrumen pengumpul data menggunakan angket dalam bentuk skala Likert. Teknik analisis data yang digunakan adalah deskriptif kuantitatif. Hasil validasi menunjukkan bahwa penilaian ahli materi diperoleh persentase 92,93\% dengan kategori sangat valid dan penilaian ahli media diperoleh persentase $89,98 \%$ dengan kategori sangat valid. Hasil uji praktikalitas oleh guru diperoleh persentase $85,4 \%$ dengan kategori sangat praktis. Hasil uji praktikalitas oleh siswa kelas X IPS 1 diperoleh persentase $87,84 \%$ dengan kategori sangat praktis.
\end{abstract}

Kata Kunci: Pengembangan, Media Pembelajaran, Prezi

\begin{abstract}
This study aims to determine, describe, and analyze the development of prezi-based learning media on the material Dynamics of the Hydrosphere and Its Impact on the Life of Class X SMA 1 Kubung. Validation is done by 2 material experts, and 2 media experts. Practicality is done by 1 geography teacher and 30 students of class X IPS 1. The data collection instrument uses a questionnaire in the form of a Likert scale. Data analysis technique used is descriptive quantitative. Validation results show that the assessment of material experts obtained percentage $92.93 \%$ with the category is very valid and expert media assessment obtained percentage $89.98 \%$ with the category is very valid. The result of practicality test by teacher obtained percentage $85,4 \%$ with very practical category. Test results practicality test by students of class X IPS 1 obtained percentage $87.84 \%$ with very practical category.
\end{abstract}

Key Words: Development, Learning Media, Prezi

\footnotetext{
${ }^{1}$ Mahasiswa Program Studi Pendidikan Geografi untukkk wisuda Maret 2018
} 


\section{PENDAHULUAN}

Kegiatan belajar merupakan kegiatan aktif peserta didik untuk membangun makna atau pemahaman terhadap suatu objek atau suatu peristiwa. Sedangkan, kegiatan mengajar merupakan upaya kegiatan menciptakan suasana yang mendorong inisiatif, motivasi dan tanggung jawab pada peserta didik untuk selalu menerapkan seluruh potensi diri dalam membangun gagasan melalui kegiatan belajar sepanjang hayat. Gagasan dan pengetahuan ini akan membentuk keterampilan, sikap, dan perilaku sehari-hari sehingga peserta didik akan berkompeten dalam bidang yang dipelajarinya. Kegiatan belajar dan mengajar inilah yang disebut orang sebagai pembelajaran (Depdiknas, 2003 :10).

Dalam proses pembelajaran, adakalanya guru dan siswa mengalami suatu hambatan dan permasalahan. Hambatan atau permasalahan tersebut bisa berasal dari guru maupun siswa. Hambatan bagi siswa misalnya, siswa kesulitan dalam menangkap penjelasan dari guru tentang konsep atau materi yang baru dipelajari bersifat sukar dengan metode mengajar konvensional. Tanpa adanya penggunaan media yang tepat maka siswa akan cenderung bosan dan jenuh dalam proses pembelajaran. Prestasi belajar siswa di sekolah sering diindikasikan dengan permasalahan belajar dari siswa dalam memahami materi. Indikasi ini dimungkinkan karena faktor belajar siswa yang kurang efektif bahkan siswa sendiri tidak merasa termotivasi dalam mengikuti pembelajaran di kelas. Sehingga menyebabkan siswa kurang atau bahkan tidak memahami materi yang berisifat sukar yang diberikan oleh guru.

Undang-Undang Republik Indonesia Nomor 14 Tahun 2005 Tentang Guru dan Dosen pasal 10 menegaskan bahwa guru harus memiliki kompetensi pedagogik, kepribadian, sosial, dan profesional. Salah satu unsur kompetensi pedagogik adalah guru mampu mengembangkan dan memanfaatkan media dan sumber belajar. Hal ini ditegaskan lagi dalam Peraturan Menteri Pendidikan Nasional Republik Indonesia Nomor 41 Tahun 2007 Tentang Standar Proses untuk Satuan Pendidikan Dasar dan Menengah bahwa dalam pembelajaran, guru wajib menggunakan sumber belajar.

Media pembelajaran adalah segala sesuatu yang dapat digunakan untuk menyalurkan pesan (bahan pembelajaran), sehingga dapat merangsang perhatian, minat, pikiran, dan perasaan siswa dalam kegiatan belajar untuk mencapai tujuan belajar. Keberhasilan penggunaan media, tidak terlepas dari bagaimana media itu direncanakan dan dipilih dengan baik. Media yang dapat mengubah perilaku siswa (behaviour change) dan meningkatkan hasil belajar siswa tertentu, tidak dapat berlangsung secara spontanitas, namun diperlukan analisis yang komprehensif dengan memperhatikan berbagai aspek yang dapat mempengaruhi keberhasilan pembelajaran.

Perkembangan ilmu pengetahuan dan teknologi (IPTEK) dewasa ini telah membawa perubahan pesat dalam 
berbagai aspek kehidupan manusia, salah satunya dalam bidang pendidikan. Dalam bidang pendidikan, perkembangan IPTEK berpengaruh terhadap perkembangan media pembelajaran, yaitu dengan dikembangkannya media pembelajaran yang berbasis komputer (ComputerBased Media). Media komputer merupakan media yang menarik, atraktif, dan interaktif. Pembelajaran melalui media komputer memberikan bekal kepada peserta didik berbagai karakter yang menjadi kekuatan dan kelemahan suatu media.

Pada sekolah-sekolah setingkat SMA (Sekolah Menengah Atas), terutama sekolah-sekolah unggulan umumnya sudah memiliki fasilitas yang modern, seperti komputer dan LCD (Liquid Crystal Display) sehingga guru pun dituntut untuk menguasai dan memanfaatkan bentuk teknologi tersebut. Secara umum, guru memanfaatkan media berbasis komputer, yaitu aplikasi Powerpoint, tetapi aplikasi tersebut ternyata belum dimanfaatkan sepenuhnya oleh guru serta belum memaksimalkan hasil pembelajaran. Hal ini dibuktikan dari hasil wawancara yang dilakukan dengan salah satu guru geografi SMA kelas X, yang mana dari hasil wawancara tersebut masih terdapat permasalahan dalam pembelajaran diantaranya adalah: (1) media pembelajaran yang digunakan masih konvensional. Kenyataannya guru lebih banyak menjelaskan materi pembelajaran dengan papan tulis dan buku ajar, guru juga terkadang menggunakan media komputer namun hanya berbatas menggunakan media
Powerpoint saja, (2) kurangnya variasi media yang digunakan dalam pembelajaran membuat siswa sulit dalam memahami materi, bahkan ada yang jenuh dalam belajar sehingga banyak siswa yang tidak memperhatikan materi pembelajaran (3) banyak guru yang belum terbiasa mengembangkan media pembelajaran. Bahkan ada kecenderungan bahwa guru belum menggunakan media yang tersedia secara optimal, sedangkan media pembelajaran harus mengikuti perkembangan teknologi, (4) pada pembelajaran geografi belum pernah menggunakan desain media presertasi pembelajaran berbasis aplikasi Prezi, proses pembelajaran masih berpusat pada guru sebagai sumber pesan (teacher centered).

Berdasarkan permasalahan diatas metode yang digunakan oleh guru dalam proses pembelajaran kurang memberikan pengaruh banyak dalam proses penyampaian pesan oleh pendidik sehingga tidak terlalu memberikan dampak positif dalam kegiatan belajar siswa dan motivasi belajar kelas. Dengan demikian perlunya penggunaan media didasarkan pada pertimbangan praktis-teoritik seperti efisiensi dan efektivitas, karena pada dasarnya mata pelajaran geografi merupakan salah satu mata pelajaran yang idealnya membutuhkan banyak media pembelajaran. Salah satu perangkat lunak yang bisa digunakan sebagai media pembelajaran geografi adalah prezi.

Prezi merupakan sebuah perangkat lunak berbasis internet atau software as a service (SaaS) yang 
digunakan sebagai media presentasi dan juga alat untuk mengeksplorasi berbagai ide di atas kanvas virtual. Prezi dapat digunakan untuk membuat presentasi linier maupun non-linier (Settle dkkk., 2011:105). Program ini menggunakan Zooming User Interface (ZUI), yang memungkinkan pengguna untuk memperbesar dan memperkecil tampilan media presentasi. Prezi dapat digunakan sebagai alat presentasi berbentuk linier maupun nonlinier, atau presentasi berbentuk peta pikir (mindmap) sebagai contoh presentasi nonlinier.

Penggunaan Prezi dapat membuat penyampaian materi lebih menarik sehingga menimbulkan daya tarik serta daya ingat peserta didik, yang pada akhirnya dapat meningkatkan hasil belajar peserta didik. Prezi juga sangat mudah dipelajari bagi pengguna pemula karena secara umum tampilan dari Prezi tidak jauh berbeda dengan program yang sudah umum digunakan.

Adapun kelebihan dari prezi menurut Rosadi (dalam Rodhi, 2014:7) adalah dapat menampung keberagaman gaya belajar, karena prezi diprogram agar dapat menampilkan media visual, audio, maupun animasi. Program aplikasi prezi juga merupakan media yang unik karena didalamnya terdapat bentuk presentasi yang sangat berbeda dengan presentasi pada umumnya. Media prezi fokus pada satu bidang slide yang disebut dengan kanvas virtual, setelah itu pengguna bisa mengeksplorasi bagian-bagian kanvas tersebut hingga bagian terkecil, sehingga konsep utama yang ingin disampaikan terlihat jelas. Penggunaan fasilitas ZUI membuat presentasi terlihat dinamis, karena kanvas bisa diperkecil, diperbesar, bahkan diputar 360 derajat. Selain itu, prezi merupakan aplikasi yang berbasis Adobe Air, sehinggga video maupun animasi flash bisa dijalankan lebih ringan daripada saat mengggunakan powerpoint. Pada awalnya aplikasi ini hanya bisa digunakan secara online namun saat ini pengguna sudah bisa menggunakan aplikasi ini secara offline dengan diluncurkannya prezi desktop.

Dengan demikian diharapkan pembelajaran dengan menggunakan media Prezi ini akan cepat membantu siswa dalam memahami materi pelajaran khususnya mata pelajaran Geografi. Media pembelajaran menggunakan aplikasi Prezi juga diharapkan membantu guru dalam menyajikan materi pada siswa secara lebih menarik. Oleh karena itu, peneliti merasa diperlukannya pengembangan media pembelajaran berbasis Prezi sebagai media pembelajaran geografi dengan judul penelitian "Pengembangan Media Presentasi Pembelajaran Berbasis Prezi pada Materi Dinamika Hidrosfer dan Dampaknya Terhadap Kehidupan".

\section{METODE PENELITIAN}

Jenis Penelitian yang akan dilakukan adalah penelitian pengembangan (Research and Development) atau disingkat denga R\&D. Sugiyono (2008) mengemukakan pengertian penelitian dan pengembangan adalah metode penelitian yang digunakan untuk menghasilkan produk tertentu dan 
menguji keefektivan produk tersebut. Untuk menghasilkan produk tertentu digunakan penelitian yang bersifat analisis kebutuhan dan untuk menguji keefektivan produk tersebut supaya dapat berfungsi di masyarakat luas diperlukan uji keefektivan produk.

Penelitian diadakan pada bulan November dan Desember, semester I tahun ajaran 2017/2018. Tempat penelitian dilaksanakan di SMA N 1 Kubung Kab. Solok.

Objek penelitian adalah media pembelajaran berbasis prezi. Media belajar yang dikembangkan ini berisi materi pembelajaran Geografi semester dua kelas X SMA yaitu Dinamika Hidrosfer dan Dampaknya terhadap Kehidupan.

Subjek penelitian terdiri dari 4 orang validator yaitu 2 orang ahli materi dan 2 orang ahli media, serta praktikalis yaitu siswa kelas $X$ IPS 1 yang berjumlah 30 siswa serta 1 orang guru geografi yang mengajar dikelas tersebut.

Prosedur pengembangan dimulai dari tahap 1) Perencanaan (planning), 2) Pengembangan draf produk (develop preliminary form of product), 3) validasi produk (validasi product), 4) uji coba produk (product trial), 5) produk akhir (final product). Instrumen yang digunakan untuk mengumpulkan data penelitian ini adalah angket validasi dan angket uji kepraktisan.

Teknik analisis data yang digunakan adalah mendeskripsikan validasi dan kepraktisan media pembelajaran berbasis Prezi yang dikembangkan: Analisis validasi media pembelajaran berbasis Prezii dilakukan dengan beberapa langkah berikut:

a. Memberikan skor jawaban dengan kriteria berdasarkan skala likert:

SS : sangat setuju dengan bobot 4

$S$ : setuju dengan bobot 3

TS: tidak setuju dengan bobot 2

STS: sangat tidak setuju dengan bobot

b. Menentukan skor tertinggi

Skor tertinggi $=$ jumlah validator $\mathrm{x}$ jumlah indikator $\mathrm{x}$ skor maksimum

c. Menjumlahkan skor total tiap validator untuk seluruh indikator.

d. Penentuan validitas dengan cara menggunakan rumus:

$$
P=\frac{f}{N} \times 100 \%
$$

$\mathrm{P}=$ Nilai akhir

$f=$ Perolehan skor

$\mathrm{N}=$ Skor maksimum

e. Memberikan penilaian validitas sesuai dengan kriteria seperti pada tabel 1 .

Tabel. 1 Kategori Kriteria Validitas

\begin{tabular}{|c|c|l|}
\hline No & \multicolumn{1}{|c|}{ Nilai } & \multicolumn{1}{|c|}{ Kriteria } \\
\hline 1 & $80 \%<\mathrm{x} \leq 100 \%$ & Sangat valid \\
\hline 2 & $60 \%<\mathrm{x} \leq 80 \%$ & Valid \\
\hline 3 & $40 \%<\mathrm{x} \leq 60 \%$ & Cukup valid \\
\hline 4 & $20 \%<\mathrm{x} \leq 40 \%$ & Kurang valid \\
\hline 5 & $0 \%<\mathrm{x} \leq 20 \%$ & Tidak valid \\
\hline
\end{tabular}

Sumber: Dimodifikasi dari Riduwan (2009)

Analisis praktikalitas didapat dari data respon guru dan siswa terhadap media pembelajaran. Angket respon guru dan siswa disusun dalam bentuk skala likert yang dimodifikasi dan disusun dengan bobot sebagai berikut : 
a. Memberikan skor untuk setiap item jawaban dengan kriteria berdasarkan skala likert:

SS : sangat setuju dengan bobot 4

S : setuju dengan bobot 3

TS : tidak setuju dengan bobot 2

STS: sangat tidak setuju dengan bobot 1

b. Menjumlahkan skor total tiap validator untuk seluruh indikator.

c. Pemberian nilai validitas dengan cara menggunakan rumus:

$$
\begin{aligned}
& P=\frac{f}{N} \mathrm{x} 100 \% \\
& \quad \text { Dimana: } \\
& \mathrm{P}=\text { Nilai akhir } \\
& f=\text { Perolehan skor } \\
& \mathrm{N}=\text { Skor maksimum }
\end{aligned}
$$

d. Setelah persentase nilai praktikalis diperoleh, dilakukan pengelompokan sesuai kriteria seperti pada tabel 2.

Tabel. 2 Kategori Kriteria Praktikalias

\begin{tabular}{|c|l|l|}
\hline No & \multicolumn{1}{|c|}{ Nilai } & \multicolumn{1}{|c|}{ Kriteria } \\
\hline 1 & $80 \%<\mathrm{x} \leq 100 \%$ & Sangat praktis \\
\hline 2 & $60 \%<\mathrm{x} \leq 80 \%$ & Praktis \\
\hline 3 & $40 \%<\mathrm{x} \leq 60 \%$ & Cukup praktis \\
\hline 4 & $20 \%<\mathrm{x} \leq 40 \%$ & Kurang praktis \\
\hline 5 & $0 \%<\mathrm{x} \leq 20 \%$ & Tidak praktis \\
\hline
\end{tabular}

Sumber: Dimodifikasi dari Riduwan (2009)

\section{HASIL DAN PEMBAHASAN}

\section{Proses Pengembangan Media Presentasi Pembelajaran Berbasis Prezi}

\section{Tahap Perencanaan}

1) Analisis Masalah

Dari hasil wawancara dengan guru mata pelajaran geografi terdapat beberapa permasalahan dalam proses pembelajaran yaitu (1) media pembelajaran yang digunakan masih konvensional. Kenyataannya guru lebih banyak menjelaskan materi pembelajaran dengan papan tulis dan buku ajar, guru juga terkadang menggunakan media komputer namun hanya berbatas menggunakan media Powerpoint saja, (2) kurangnya variasi media yang digunakan dalam pembelajaran membuat siswa sulit dalam memahami materi, bahkan ada yang jenuh dalam belajar sehingga banyak siswa yang tidak memperhatikan materi pembelajaran (3) banyak guru yang belum terbiasa mengembangkan media pembelajaran. Bahkan ada kecenderungan bahwa guru belum menggunakan media yang tersedia secara optimal, sedangkan media pembelajaran harus mengikuti perkembangan teknologi, (4) pada pembelajaran geografi belum pernah menggunakan desain media presertasi pembelajaran berbasis aplikasi Prezi, proses pembelajaran masih berpusat pada guru sebagai sumber pesan (teacher centered). Maka dari itu, peneliti memutuskan mengembangkan media pembelajaran berbasis Prezi yang dapat membantu siswa dalam belajar.

2) Analisis Kurikulum Di SMA

Dalam pelaksanaan pembelajaran SMAN 1 Kubung melaksanakan kurikulum 2013 yang mengacu pada Permendikud no.21 tahun 2016 tentang standar isi pendidikan dasar dan menengah yang memuat tentang tingkat 
kompetensi dan kompetensi inti sesuai dengan jenjang dan jenis pendidikan tertentu.

Analisis kurikulum dilakukan dengan menganalisis kompetensi inti serta kompetensi dasar, kemudian menentukan materi yang dianggap sesuai untuk diajarkan menggunakan media pembelajaran prezi. Dari analisis tersebut kemudian diputuskan untuk mengangkat materi dinamika hidrosfer dan dampaknya terhadap kehidupan Kelas X SMA.

3) Analisis Siswa

Berdasarkan hasil analisis yang dilakukan terhadap peserta didik kelas X SMA N 1 Kubung, maka media pembelajaran berbasis Prezi pada materi dinamika hidrosfer ini sudah sesuai dengan kondisi peserta didik. Analisis yang penulis lakukan didapat beberapa karakteristik siswa yaitu sebagai berikut:

a) Siswa kelas $\mathrm{X}$ berjumlah 30 orang dengan usia rata-rata 1617 tahun. Jumlah siswa laki-laki sebanyak 8 orang dan siswa perempuan sebanyak 22 orang

b) Siswa sulit memahami materi dinamika hidrosfer dan dampaknya terhadap kehidupan karena materi ini bersifat abstrak dan sulit untuk divisualisasikan.

c) Minat dan perhatian siswa masih kurang terhadap pembelajaran geografi, ini disebabkan guru kurang inovatif dalam menggunakan media yang tepat untuk pembelajaran yang bersifat abstrak seperti materi dinamika hidrosfer dan dampaknya terhadap kehidupan.

d) Siswa bersifat sangat terbuka dengan perkembangan ilmu pengetahuan dan teknologi (IPTEK)

\section{Pengembangan Produk Awal}

\section{1) Penyusunan Materi}

a) Menentukan dan memahami $\mathrm{KI}$ dan KD dinamika hidrosfer dan dampaknya terhadap kehidupan.

b) Menentukan indikator yang mendukung dari KD.

c) Menentukan tujuan pembelajaran yang mendukung dari indikator.

d) Menentukan materi yang akan digunakan pada aplikasi Prezi sebagai media pembelajaran.

e) Merancang peta konsep yang menghubungkan materi dalam materi dinamika hidrosfer dan dampaknya terhadap kehidupan

f) Membuat uraian materi yang terdapat dalam pokok bahasan dinamika hidrosfer dan dampaknya terhadap kehidupan.

g) Mencari gambar serta video yang sesuai dengan submateri serta untuk mendukung materi dinamika hidrosfer dan dampaknya terhadap kehidupan.

h) Mencari nilai religi yang sesuai dengan materi dinamika hidrosfer dan dampaknya terhadap kehidupan untuk mendukung materi.

i) Membuat soal-soal latihan yang berhubungan dengan materi pada setiap pertemuan. 


\section{2) Pembuatan Media}

a) Pembuatan Sketsa

Adapun hal-hal yang dibuat dalam pembuatan sketsa yaitu: halaman petunjuk, halaman kompetensi dasar, materi, video serta latihan/evaluasi.

b) Pengumpulan Objek Media Adapun yang harus dikumpulkan yaitu: materi konsep dasar, gambar/foto, video, animasi yang berkaitan dengan materi.

c) Membuat desain media

Setelah membuat sketsa dan mengumpulkan materi, maka tahap selanjutnya adalah membuat desain media prezi. Karena materi yang dibuat cukup banyak maka penulis membatasi satu contoh dari langkah pembuatan media menggunakan aplikasi Prezi.

\section{Validasi Produk}

Validasi pada pengembangan produk media pembelajaran berbasis prezi ini melibatkan dua orang ahli materi yaitu dosen geografi FIS UNP yang mengajar mata kuliah Hidrosfer yang mana validator 1 Bapak Drs. Helfia Edial, MT dan validator 2 Ibuk Widya Prarikeslan, S.Si, M.Si. Sedangkan ahli media adalah 2 orang dosen yang memegang mata kuliah media pembelajaran yang mana validator I berasal dari jurusan KTP FIP UNP (Nofri Hendri, S.Pd, M.Pd) sedangkan validator II berasal dari jurusan Geografi FIS UNP (Bayu Wijayanto, M.Pd).

\section{Uji Coba Produk}

Uji coba produk dilakukan pada 1 orang guru geografi yang bernama Rini Amalia S.Pd dan siswa kelas X IPS 1 di SMA N 1 Kubung dengan jumlah siswa 30 orang.

\section{Hasil Produk Akhir}

Setelah tahap validasi dan uji coba produk, maka diperoleh hasil penelitian dan pengembangan berupa produk media pembelajaran berbasis prezi pada materi dinamika hidrosfer dan dampaknya terhadap kehidupan yang layak digunakan dalam pembelajaran.

\section{Deskripsi Validasi dan Praktikalitas Produk}

\section{Deskripsi Data Validasi}

\section{1) Ahli Materi}

Hasil penilaian materi mencakup aspek kesesuaian isi/materi, kebahasaan, sajian, dan kegrafisan. Penilaian keempat aspek tersebut dapat dilihat pada tabel 3 dibawah ini:

Tabel 3. Hasil Penilaian Ahli

\begin{tabular}{|l|l|l|l|}
\multicolumn{5}{|c|}{ Materi } \\
\hline No & Aspek & $\begin{array}{l}\text { Rerata } \\
(\%)\end{array}$ & Kategori \\
\hline A & $\begin{array}{l}\text { Kesesuaian } \\
\text { Isi/Materi }\end{array}$ & $92,05 \%$ & $\begin{array}{l}\text { Sangat } \\
\text { Valid }\end{array}$ \\
\hline B & $\begin{array}{l}\text { Kebahasaa } \\
\text { n }\end{array}$ & $87,5 \%$ & $\begin{array}{l}\text { Sangat } \\
\text { Valid }\end{array}$ \\
\hline C & Sajian & $87,5 \%$ & $\begin{array}{l}\text { Sangat } \\
\text { Valid }\end{array}$ \\
\hline D & Kegrafikan & $92,86 \%$ & $\begin{array}{l}\text { Sangat } \\
\text { Valid }\end{array}$ \\
\hline \multicolumn{2}{|l|}{ Total Rerata } & $89,98 \%$ & $\begin{array}{l}\text { Sangat } \\
\text { Valid }\end{array}$ \\
\hline
\end{tabular}

Sumber : Olahan Data primer 2017

Dari data di atas dapat dilihat bahwa rata-rata jumlah nilai 
dari kedua validator materi adalah 89,98\% dengan kategori "Sangat Baik". Secara keseluruhan untuk aspek materi sudah berada pada kategori sangat baik. Pada variabel Kesesuaian Isi/Materi memperoleh rata-rata skor $92,05 \%$, sedangkan kebahasaan memperoleh skor $87,5 \%$, variabel penyajian materi memperoleh rata-rata skor $87,5 \%$, variabel kegrafikan memperoleh rata-rata skor $92,86 \%$.

\section{2) Ahli Media}

Hasil penelitian mencakup aspek tujuan dan manfaat, kualitas teknis, kualitas pemograman, dan kebahasaan. Penilaian keempat aspek tersebut dapat dilihat pada tabel 4 dibawah ini:

Tabel 4. Hasil Penilaian Ahli

\begin{tabular}{|c|c|c|c|}
\hline \multicolumn{4}{|c|}{ Media } \\
\hline No & Aspek & $\begin{array}{l}\text { Rerata } \\
(\%)\end{array}$ & Kategori \\
\hline $\mathbf{A}$ & $\begin{array}{l}\text { Tujuan Dan } \\
\text { Manfaat }\end{array}$ & $95,31 \%$ & $\begin{array}{l}\text { Sangat } \\
\text { Valid }\end{array}$ \\
\hline B & $\begin{array}{l}\text { Kualitas } \\
\text { Teknis }\end{array}$ & $88,89 \%$ & $\begin{array}{l}\text { Sangat } \\
\text { Valid }\end{array}$ \\
\hline $\mathrm{C}$ & $\begin{array}{l}\text { Kualitas } \\
\text { Pemograma } \\
\text { n }\end{array}$ & $100 \%$ & $\begin{array}{l}\text { Sangat } \\
\text { Valid }\end{array}$ \\
\hline D & $\begin{array}{l}\text { Kebahasaa } \\
n\end{array}$ & $87,5 \%$ & $\begin{array}{l}\text { Sangat } \\
\text { Valid }\end{array}$ \\
\hline Tot & Rerata & $92,93 \%$ & $\begin{array}{l}\text { Sangat } \\
\text { Valid }\end{array}$ \\
\hline
\end{tabular}

Sumber : Olahan Data primer 2017

Dari data diatas dilihat bahwa rata-rata jumlah nilai dari kedua validator media adalah 92,93\% dengan kategori "Sangat Baik". Secara keseluruhan untuk aspek media sudah berada pada kategori sangat baik. Pada aspek Tujuan dan Manfaat memperoleh skor 95,31\%, aspek kualitas teknik memperoleh skor $88,89 \%$, aspek kualitas pemograman memperoleh skor $100 \%$ dan aspek kebahasaan memperoleh skor $87,5 \%$.

\section{Deskripsi Data Praktikalitas}

\section{1) Hasil Praktikalitas Guru}

Variabel yang dinilai pada praktikalitas produk ini mencakup aspek tujuan dan manfaat, kualitas teknis, kebahasaan, kesesuaian materi, sajian, waktu, evaluasi, kemudahan penggunaan. Penilaian delapan aspek tersebut dapat dilihat pada tabel 5 dibawah ini:

Tabel 5. Hasil Penilaian Guru

\begin{tabular}{|c|l|c|l|}
\hline No & Aspek & $\begin{array}{c}\text { Rerat } \\
\text { a (\%) }\end{array}$ & $\begin{array}{l}\text { Kategor } \\
\text { i }\end{array}$ \\
\hline A & $\begin{array}{l}\text { Tujuan dan } \\
\text { Manfaat }\end{array}$ & $\begin{array}{c}82,14 \\
\%\end{array}$ & $\begin{array}{l}\text { Sangat } \\
\text { Praktis }\end{array}$ \\
\hline B & $\begin{array}{l}\text { Kualitas } \\
\text { Teknik }\end{array}$ & $\begin{array}{c}77,78 \\
\%\end{array}$ & Praktis \\
\hline C & Kebahasaan & $\begin{array}{c}81,25 \\
\%\end{array}$ & $\begin{array}{l}\text { Sangat } \\
\text { Praktis }\end{array}$ \\
\hline D & $\begin{array}{l}\text { Kesesuaian } \\
\text { Materi }\end{array}$ & $87,5 \%$ & $\begin{array}{l}\text { Sangat } \\
\text { Praktis }\end{array}$ \\
\hline E & Sajian & $75 \%$ & Praktis \\
\hline F & Waktu & $\begin{array}{l}\text { Sangat } \\
\text { Praktis }\end{array}$ \\
\hline G & Evaluasi & $75 \%$ & Praktis \\
\hline H & $\begin{array}{l}\text { Kemudahan } \\
\text { Penggunaan }\end{array}$ & $87,5 \%$ & $\begin{array}{l}\text { Sangat } \\
\text { Praktis }\end{array}$ \\
\hline \multicolumn{2}{|c|}{ Total Rerata } & 83,79\% \\
\hline \multicolumn{3}{|c|}{ Kategori } & Sangat Praktis \\
\hline
\end{tabular}

Sumber : Olahan Data primer 2017

Dari data di atas dapat dilihat bahwa rata-rata jumlah nilai dari praktikalitas guru adalah 83,79\% dengan kategori "Sangat Praktis". Pada aspek Tujuan dan Manfaat 
memperoleh rata-rata skor $82,14 \%$, kualitas teknik memperoleh skor rata-rata $77,78 \%$, kebahasaan memperoleh skor $81,25 \%$, variabel kesesuaian materi memperoleh ratarata skor $87,5 \%$, variabel sajian $75 \%$, variabel waktu memperoleh skor $100 \%$ variabel evaluasi memperoleh skor $75 \%$, sedangkan variabel kemudahan penggunaan memperoleh rata-rata skor $87,5 \%$.

\section{2) Hasil Praktikalitas Siswa}

Variabel yang dinilai pada uji coba produk ini mencakup aspek tujuan dan manfaat, kualitas teknis, waktu, evaluasi, kemudahan penggunaan. Penilaian kelima aspek tersebut dapat dilihat pada tabel 6 dibawah ini:

Tabel 6. Hasil Uji Coba Siswa

\begin{tabular}{|c|l|l|l|}
\hline No & Aspek & $\begin{array}{l}\text { Rata- } \\
\text { rata } \\
(\%)\end{array}$ & $\begin{array}{l}\text { Kategor } \\
\text { i }\end{array}$ \\
\hline A & $\begin{array}{l}\text { Tujuan dan } \\
\text { Manfaat }\end{array}$ & $\begin{array}{l}88,93 \\
\%\end{array}$ & $\begin{array}{l}\text { Sangat } \\
\text { Praktis }\end{array}$ \\
\hline B & $\begin{array}{l}\text { Kualitas } \\
\text { Teknis }\end{array}$ & $87 \%$ & $\begin{array}{l}\text { Sangat } \\
\text { Praktis }\end{array}$ \\
\hline C & Waktu & $90 \%$ & $\begin{array}{l}\text { Sangat } \\
\text { Praktis }\end{array}$ \\
\hline D & Evaluasi & $75 \%$ & Praktis \\
\hline E & $\begin{array}{l}\text { Kemudahan } \\
\text { Penggunaan }\end{array}$ & $87,5 \%$ & $\begin{array}{l}\text { Sangat } \\
\text { Praktis }\end{array}$ \\
\hline \multicolumn{2}{|c|}{ Rata-rata } & \multicolumn{2}{|c|}{8 ,19\% } \\
\hline \multicolumn{2}{|c|}{ Kategori } & \multicolumn{2}{|c|}{ Sangat Layak } \\
\hline
\end{tabular}

Sumber : Olahan Data primer 2017

Dari data di atas dapat dilihat bahwa rata-rata jumlah nilai dari praktikalitas siswa adalah $88,19 \%$ dengan kategori "Layak". Pada variabel Tujuan dan Manfaat memperoleh rata-rata skor $88,93 \%$, kualitas teknik memperoleh skor rata-rata $87 \%$, variabel waktu memperoleh skor $90 \%$, variabel evaluasi memperoleh skor $75 \%$, sedangkan variabel kemudahan penggunaan memperoleh rata-rata skor $87,5 \%$.

Hasil penelitian dan pengembangan ini berupa produk media pembelajaran berbasis prezi pada materi dinamika hidrosfer dan dampaknya terhadap kehidupan. Proses pengembangan media pembelajaran berbasis prezi ini mengacu pada model Borg \& Gall. Adapun prosedur kerja yang dilakukan dengan pendekatan Borg \& Gall melalui beberapa tahap yaitu: tahap perencanaan, pengembangan, validasi, uji coba produk, produk akhir.

Tahap perencanaan dimulai dari analisis masalah, analisis kurikulum di SMA, serta analisis siswa. Pada tahap pengembangan produk awal dimulai dari penyusunan materi yang disesuaikan dengan kurikulum 2013 dan membuat media prezi dengan tahapan 1) pembuatan sketsa, 2) pengumpulan objek media, 3) membuat desain media.

Uji validitas media prezi diperoleh dari pengisian lembar validasi yang dilakukan oleh tim validator ahli materi dengan hasil $89,98 \%$ dengan kategori sangat valid, dan ahli media dengan hasil 92,93\% dengan kategori sangat valid, hal ini sesuai dengan kriteria penilaian Riduwan (2012). Hasil penilaian menunjukan bahwa 
multimedia yang dikembangkan telah memenuhi syarat didaktik, konstruksi dan teknik. Dari hasil validasi juga diperoleh beberapa saran dan komentar yang kemudian dilanjutkan dengan revisi.

Pengujian praktikalitas media prezi dilakukan melalui pengisian angket praktikalitas oleh responden yaitu guru mata pelajaran geografi dan siswa kelas $\mathrm{X}$ SMA $\mathrm{N} 1$ Kubung sebanyak 30 orang. Hasil praktikalitas yang dilakukan diperoleh rata-rata nilai praktikalitas siswa sebesar $87,84 \%$ dengan kategori sangat praktis. Hasil praktikalitas oleh guru mata pelajaran geografi diperoleh nilai praktikalitas sebesar $85,4 \%$ dengan kategori sangat praktis, hal ini sesuai dengan kriteria penilaian Riduwan (2012).

Setelah dikatakan valid dan praktis maka produk media pembelajaran berbasis prezi ini sudah layak untuk digunakan dalam pembelajaran geografi.

\section{PENUTUP}

\section{Kesimpulan}

Berdasarkan hasil penelitian pengembangan media presentasi pembelajaran berbasis prezi pada materi dinamika hidrosfer dan dampaknya terhadap kehidupan pengembangan media presentasi pembelajaran berbasis prezi ini menggunakan model pengembangan Borg \& Gall yang sudah diadaptasi kedalam lima tahap yaitu: 1) perencanaan, 2) pengembangan, 3) validasi, 4) uji coba produk dan 5) produk akhir. Penilaian produk media pembelajaran berbasis prezi dilakukan oleh 2 orang ahli materi, 2 orang ahli media, guru mata pelajaran geografi serta siswa SMA Negeri 1 Kubung kelas X IPS 1 sebanyak 30 orang siswa.

Validasi media presentasi pembelajaran berbasis prezi pada materi dinamika hidrosfer dan dampaknya terhadap kehidupan berada pada kategori valid. hal ini berdasarkan penilaian dari ahli materi dengan nilai akhir $89.98 \%$, untuk penilaian dari ahli media dengan nilai akhir 92,93\%. Berdasarkan deskripsi hasil validasi oleh validator memiliki kategori sangat valid.

Praktikalis media presentasi pembelajaran berbasis prezi pada materi dinamika hidrosfer dan dampaknya terhadap kehidupan berada pada kategori valid, hal ini berdasarkan penilaian dari praktisi dalam hal ini adalah guru geografi dengan nilai akhir $85,4 \%$, untuk penilaian dari praktisi dalam hal ini adalah siswa dengan nilai akhir adalah 87,84\%. Berdasarkan deskripsi hasil validasi oleh praktikalis memiliki kategori sangat praktis. Dengan demikan maka media presentasi pembelajaran berbasis prezi pada materi dinamika hidrosfer dan dampaknya terhadap kehidupan layak untuk digunakan dalam pembelajaran geografi.

\section{Saran}

Berdasarkan pembahasan dan kesimpulan sebagai tindak lanjut untuk peneitian dan pengambangan berikutnya, adapun beberapa saran sebagai berikut: 1) guru perlu memnafaatkan dengan baik fasilitas 
teknologi informasi yang ada dalam proses pembelajaran, seperti menggunakan media pembelajaran prezi dan media pembelajaran lainnya, 2) perlu adanya penelitian dan pengambangan lebih lanjut tentang media pembelajaran prezi yang mencakup semua aspek dalam pembelajaran, 3) dengan adanya penelitian pengambangan ini diharapkan adanya penelitian pengembangan lain untuk penunjang pembelajaran lainnya.

\section{DAFTAR PUSTAKA}

Permendiknas. 2003. Peraturan Menteri Pendidikan Nasional Republik Indonesia Nomor, 10 Tahun 2003, tentang Kegiatan Pembelajaran

Peraturan Menteri Pendidikan Nasional. 2016. Peraturan Menteri Pendidikan Nasional, Nomor 21 Tahun 2016, tentang Standar Isi Pendidikan Dasar dan Menengah.

Riduwan. (2012). Skala pengukuran Variabel-variabel penelitian pendidikan. Bandung: alfabeta

Rodhi, Mohhamad Yusuf. 2014. Pengembangan Media Pembelajaran Berbasis PREZI untuk Meningkatkan Keterampilan Berpikir Kritis pada Materi Kalor. Surabaya : Universitas Negeri Surabaya.

Settle, Q., Katie M. A., Lauri M. B. 2011. Using Prezi in the classroom. Jurnal NACTA vol. 55 No. 4. Diakses Minggu, 07 Desember 2016. Pukul 11.16 WIB.
Sugiyono. 2008. Metode Penelitian Pendidikan Pendekatan Kuantitatif, Kualitatif dan $R \& D$. Bandung: Alfabeta.

Undang-undang. 2003. Undang-undang RINomor 20 Tahun 2003, Tentang Standar Pendidikan Nasional.

Undang-undang Republik Indonesia. 2005. Undang-undang Republik Indonesia, Nomor 14 Tahun 2005, Tentang Guru dan Dosen Pasal 10. 